\title{
Turning a Hobby into Millions
}

\author{
Philip King \\ Bookstore Entrepreneur
}

$B$ efore Philip King sold his five bookstores in Christchurch roughly 10 years ago to Whitcoulls, a large Australianowned bookstore and office supplies operation, he hardly fancied himself as an entrepreneur. Books were his passion: He loved to read. However, his first job was selling barbeque charcoal to New Zealand's South Island residents.

NEJE: Philip, it sounds a bit strange to be talking to such a successful entrepreneur who got his start in selling barbeque charcoal.

Philip: I suppose it does, but it was my father's business, and it was a place for me to start after university. I grew up in Christchurch and loved studying the liberal arts, especially political science and English literature. However, right after graduation, I got married and had to start working for a living; it was easy enough just to go into my family's business.

\section{NEJE: What came next?}

Philip: I started corporate life at the bottom, so to speak, by working for Nabisco in its Sales and Merchandising Department. I spent several years filling supermarket shelves with product. It was humbling compared to what my friends were doing with their university degrees! However, this turned out later to be invaluable experience. I learned all about how to present product to its best advantage on the shelf, what it took to improve market share, and how to compete effectively against other manufacturers.

\section{NEJE: Is that when you started your own bookstore?}

Philip: No, not right away. I decided to leave corporate life and become a teacher. I took a position in a small town with just 20,000 residents. I was put in charge of 30 youngsters who were disciplinary problems; many of them could not read or write at a functional level. It was an enormous challenge.

Several years into it, I found that my hobby of collecting books was getting a bit out of hand since our home could only hold so many. I decided to set up a bookshop where I could share my passion for reading and collecting books with others. I took a punt and borrowed all the money I needed to get the store going. It seemed like quite a risk at the time. In fact, the first time I approached the local bank for $\$ 400$ (New Zealand) for start-up money, they turned me down because I hadn't put anything in writing. With some coaching, I learned how to put together a business plan; and it was then that the bank gave me the money.

\section{NEJE: Apparently your bookstore did quite well.}

Philip: My very first effort was a modest success, but I realized I could never make much money in such a lightly populated area. I sold the bookstore; and we moved to Auckland, North Island, the largest commercial city in the country. I found the equivalent of 4,000 square feet of commercial space, gutted the area, hired an architect, and came up with a new look to selling books.

Borrowing from what I had learned by working at Nabisco, I knew that the way I presented my books and used every available meter of wall space would be paramount to my success. Movable flat tables were used to highlight best-selling authors and to move bargain lots. Signage, which was typically poor in many bookshops, was another opportunity to do something different. Fixtures were also critical. Everything was rethought, from the floor to the ceiling. I wanted my store to be userfriendly, bright, and very welcoming.

The first year we generated \$286,000 (New Zealand) in sales. By the third year, we topped $\$ 1$ million. My theories about how books could be better merchandised paid off. We were growing exponentially. That's not to say everything in the store reflected just my concepts. I visited hundreds of bookstores throughout the world, and I always looked to take back the best ideas I came across.

NEJE: Just out of curiosity, what do you consider to be the best bookstores? Borders Books? Barnes E Noble?

Philip: No, it would be Waterstones in the United Kingdom and Powell's in the United States. I am especially impressed with the Powell's website.

\section{NEJE: When did you open the second store?}

Philip: Not in Auckland. In fact, the family missed being in Christchurch so much that I sold the Auckland store, and we all moved back to my hometown in the South 
Island during 1985. I started my first store there under the name of "Paper Plus." It was part of a robust association group of 80 independent booksellers with a strong combined buying power that one individual could never hope to match.

\section{NEJE: "Paper Plus?" What happened to the bookstore?}

Philip: Oh, it was a bookstore, but you have to understand, in relatively low population density areas, you need to sell stationery as well as books. It's not like in the United States.

\section{NEJE: That's when you opened a second store.}

Philip: Yes, in 1987, but it was in Dunedin, several hundred kilometers to the south. Dunedin is a big university town. I knew I couldn't effectively manage both locations, so I decided to hire someone whom I could trust and delegate much of the managerial functions. It was a great decision all around. In our first year, we generated \$2.3 million (New Zealand) in sales, and we never looked back.

\section{NEJE: You eventually opened a total of five different bookstore locations.}

Philip: Yes. In 1988, we opened a third "Paper Plus" in a new Christchurch mall. We no longer needed bank loans; our cash flow was so good we were able to fund our expansions internally. By then I had learned how to read a balance sheet with great care, and I always randomly checked on vendor invoices to make sure we were being treated fairly.

I wasn't enthusiastic about the mall location. I only considered it because one of my staff members was so enthusiastic about the location. In fact, my feelings were that bookstores should be freestanding buildings with as much walk-by traffic as you can muster. At first, I rejected the mall developer's offer and walked away. Three hours later, the developer called me back and put a much better offer on the table.

By 1989, we had four stores operating in the Christchurch area and the one in Dunedin. By growing to this level, we finally had the merchandising and advertising synergy I had always wanted. Things really started to click. I left the "Paper Plus" association umbrella and renamed the stores "Philip King Booksellers." It was uncomfortable at first to see my name on the stores and in our advertising. I am not by nature a person who is selfpromoting, but it seemed to be a good idea because it was time to break away from the association. Putting my name on the business gave us credibility both with our suppliers and with the buying public.
By 1993, we had a staff of 100 employees, and we were selling in the neighborhood of $\$ 10$ million (New Zealand) annually.

NEJE: With all this success, with the rapid growth and company expansion, you could have sat back and just watched the dollars roll in. But you decided to cash it all in. How come?

Philip: Sometimes there are business offers you simply cannot say "no" to. But let me provide the context for my decision to sell.

Christchurch may be the renowned jumping-off point for ships and planes to explore Antarctica, but the city actually has a temperate climate because it lies between the Southern Alps to the west of the city and the Pacific Ocean to the east. Snow, while not rare, is usually light and melts the next day.

In 1993, I was leaving on a business trip; but everything closed down, including the airport, for two days because we had the equivalent of a four-inch snowfall. Four inches! That's nothing to many Americans, but to folks in Christchurch it was practically a blizzard.

The newspapers made a big deal of this two-day citywide shutdown, and I was intrigued with the idea that somehow there was a book in all this. Imagine the number of people who took photographs those two days and the memories everyone had! So I called up the local newspaper publisher and suggested that he should take all of his staff's photos and make it into a book.

He turned me down. He said he was in the newspaper business, not the book business. So I called the business page editor and got the same results. No way.

I wouldn't let go of the idea. I put an advertisement in the newspaper for local folks to send in their photos, promising to publish the best 100 or so of those submitted. We received thousands of photos in response to that one display ad. We were so overwhelmed with them all that I had to set up an editorial team with the directive to pick enough snapshots to fill up a 60-page book. Each person who sent in a photo we published received $\$ 100$ (New Zealand) and two free copies of the book. The rest of the photos were returned.

We called the book The Big Snow, and the editorial team turned the project around in five weeks. We saved a lot of time by having the books printed locally even though it was more expensive. Timing was critical. I went way out on a limb and authorized a run of 7,500 copies.

NEJE: The book must have been very popular.

Philip: Sure was. Word spread like wildfire. We sold out all of our copies in one week. Eventually, sales totaled 
28,500 copies. That's huge for Christchurch; our total population is only 200,000 . Everyone who sent in a photo that was included in the book must have purchased at least 10 books each to send to family and friends. It was the talk of the town.

It was only natural that some of the book's customers would attempt to buy the book at Whitcoulls, our biggest competitor. An N.Z. entrepreneur owns them and they are much, much larger in New Zealand than we ever were. When one of their staff called over to us to order books, I refused to sell them The Big Snow. We considered it an exclusive since we had published the book on our own and I had sole selling rights.

Word got back to Whitcoulls management, and they were furious. They threatened to sue.

\section{NEJE: Wasn't that intimidating?}

Philip: Absolutely not. In fact, I ended up begging the owner to sue us. Can you imagine the newspaper headlines?

\section{“Big New Zealand Bookseller Sues Philip King Stores Over Rights to Sell King's Book."}

The publicity would have been priceless, and I doubt they had a legal right to force us to sell them the book anyway. The fellow hung up on me; he was angry at my hurting the credibility of his bookstores. Can you imagine what happened in all the Whitcoulls around Christchurch? Every time folks came in to buy The Big Snow, the staff had to admit they didn't have the book; and they either sent them to us or made believe they didn't know where the book was being sold!

Let me tell you, it was one beautiful feeling. We went on to publish other books about the Canterbury region, Auckland, Wellington, and the Otago Peninsula.

Not long afterward, the Whitcoulls owner called and said he wanted to meet with me. I had no idea what he wanted. We met in Auckland and that's when he offered to buy me out.

NEJE: You didn't have to sell.

Philip: They made me a generous offer.

NEJE: Yet weren't the bookstores all about following your passion and enjoying going to work every day?

Philip: After nearly eight years working what seemed 'round the clock, I was tired. I needed a sabbatical. I enjoyed mentoring my staff and watching employees grow into their positions and gradually take over more and more responsibility, but I also felt it was time to trav- el for pleasure and not just for business. I bought a 2,200acre farm with some of the money, and I've enjoyed the good life.

NEJE: What happened to the bookstores?

Philip: They changed the name to "Books \& More." The stores seem to be doing just fine.

\section{NEJE: And you?}

Philip: I'm having fun "working" 10 months a year as the University of Canterbury's bookstore manager. I don't need the money. But they called me last year and said they were desperate to improve the store's operation. I came by, and I was aghast at how poorly everything was being merchandised and presented. So I took this job on as a hobby. We changed the bookstore around completely, and now sales revenue has shot up.

NEJE: How long will you stay here at the university bookstore?

Philip: It's hard to say. I'm thinking of subdividing the farm and possibly developing parts of it for upmarket housing. Who knows? I'll find something to keep me busy.

$-L . W$. 